\title{
RESPONSE OF SOIL PHOSPHATASES TO THREE DIFFERENT IONIC LIQUIDS WITH HEXAFLUOROPHOSPHATE ANION
}

\author{
Arkadiusz Telesiński', Martyna Śnioszek', Robert Biczak², Barbara Pawłowska² \\ 1 Department of Plant Physiology and Biochemistry, West Pomeranian University of Technology, Słowackiego \\ 17, 71-434 Szczecin, Poland, e-mail: Arkadiusz.Telesinski@zut.edu.pl \\ 2 Department of Biochemistry and Ecotoxicology, Jan Długosz University in Częstochowa, 13/15 Armii Krajowej \\ Av., 42-200 Częstochowa, Poland
}

Received: 2016.12.15

Accepted: 2017.01.16

Published: 2017.03.01

\begin{abstract}
The aim of this study was to determine the effect of three different ionic liquids (ILs): 1-butyl-1-methylpyrrolidynium hexafluorophosphate [Pyrrol][PF6], 1-butyl-1-methylpiperydynium hexafluorophosphate [Piper][PF6] and 1-butyl-4-methylopirydynium hexafluorophosphate [Piryd][PF6] on phosphatase activities in soil. The pot experiment was carried out on loamy sand (Corg content $9.0 \mathrm{~g} / \mathrm{kg}$ ) with spring barley as a tested plant. The ILs was used at the dosages of $0,1,10,50,100,400,700$ and 1000 $\mathrm{mg} / \mathrm{kg}$ dry matter (DM). On day 14, soil samples were collected and activities of alkaline phosphomonoesterase, acid phosphomonoesterase, phosphotriesterase and inorganic pyrophosphatase were determined. Based on the analysis of the effect measure $\eta^{2}$ by variance analysis - ANOVA - the percentage shares of all variable factors affecting the activity of phosphatases were also defined. Obtained results showed that the application of different dosages of all ILs caused mainly non-significant changes in phosphatase activity. Changes in activity of phosphatases were often not dependent on IL dosages. The most sensitive for ILs were both phosphomonoesterases. The type of ILs had the highest percentage participation in formation of acid phosphomonoesterase activity, while dosages of ILs affected mainly alkaline phosphomonoesterase and phosphotriesterase activities.
\end{abstract}

Keywords: ionic liquids, soil, phosphomonoesterases, phosphotriesterase, inorganic pyrophosphatase, resistance index

\section{INTRODUCTION}

In the search for environmentally friendly chemicals, especially solvents, the world of science has focused on ionic liquids - ILs [Biczak et al., 2016a]. Ionic liquids compose a group of chemical compounds which have an ionic nature, they consist an organic cation and inorganic or organic anion, and their melting point does not exceed $100^{\circ} \mathrm{C}$. These compounds play a very important role in scientific investigations as well as in industrial organic synthesis, both in high-tonnage productions as well as low-tonnage technologies of high added-value chemicals and materials. Ionic liquids are mostly used as alter- native media and/or catalysts for desired chemical reactions [Borowiecki et al., 2015]. Due to the very low vapor pressure, these compounds are often referred to as environment-friendly ,green solvents" [Romero et al., 2008]. However the total perception of this compounds as environmentfriendly may lead to their improper experimental design and utilization. Important is also the fact that potential ecotoxity and existence of majority of ILs present in the environment have not been fully understood yet [Telesiński and Sułkowska, 2016], nevertheless the toxic effects of ILs on microorganisms, plants, aquatic organisms and soil animals have been recently evaluated [Docherty and Kulpa, 2005; Dong et al., 2013; Li et al., 
2010; Liu et al., 2015; Biczak, 2016]. Due to the fact that ILs possess some excellent properties, such as considerable solubility in water and resistance to degradation, their environmental risks may enhance together with increasing scale of the ILs usage [Sun et al., 2017].

The ILs may enter the soil, among other things, as a result of accidental spillage, use of compost from sewage sludge or landfill leachate [Telesiński and Sułkowska, 2016]. According to Bielińska et al. [2005] phosphatases are the most frequent measured enzymes in soil affected with anthropogenic contamination. Activity of enzymes is one of the best indicators of any changes in soil environment caused by natural and anthropogenic factors, especially organic xenobiotics. Moreover changes in soil enzymatic activity are one of the earliest signals indicating some fluctuations in the intensity of environmental life processes [Bielińska and Mocek-Płóciniak, 2010].

The name phosphatase describes a group of enzymes that hydrolyses esters as well as anhydrides of phosphoric acid. There are different phosphatases in soils: phosphomonoesterase, phosphodiesterase, phosphotriesterase, phospholipase, inorganic pyrophosphatase and enzymes acting on P-N-bonds [Wang et al., 2011].

This paper presents the effect of three different ionic liquids with hexafluorophosphate anion on the activities of alkaline phosphomonoesterase, acid phosphomonoesterase, phosphotriesterase and inorganic pyrophosphatase in soil.

\section{MATERIAL AND METHODS}

The ionic liquids, such as: 1-butyl-1-methylpyrrolidynium hexafluorophosphate [Pyrrol] [PF6], 1-butyl-1-methylopiperydynium hexafluorophosphate [Piper][PF6] and 1-butyl-4-methylpirydynium hexafluorophosphate [Piryd][PF6] were used in the experiment.

A pot experiment was carried out in the vegetation hall of the Department of Biochemistry and Ecotoxicology at Jan Długosz University in Częstochowa. A monocotyledonous plant, the spring barley (Hordeum vulgare L.) was used in the experiment. Fifteen seeds of the plants, originating from the same source, were sown into a 90 mm-diameter plastic plant pot that was filled with the reference soil and a soil thoroughly mixed with the studied ILs. The ILs was used at the dosages of $0,1,10,50,100,400,700$ and 1000 $\mathrm{mg} / \mathrm{kg}$ dry matter (DM). The soil used in the experiment was loamy sand with a dissolved matter containing of approximately $10 \%$, an organic carbon of $9.0 \mathrm{~g} / \mathrm{kg}$ and $\mathrm{pH}$ in $1 \mathrm{M} \mathrm{KCl}$ equal to 6.0 . Throughout the testing period (14 days), constant substrate moisture content at the level required for the plants ( $70 \%$ field water capacity), a constant temperature $20 \pm 2^{\circ} \mathrm{C}$ and a constant illumination of $170 \mu \mathrm{mol} / \mathrm{m}^{2} / \mathrm{s}$ were maintained in the system of $16 \mathrm{~h}$ on day and $8 \mathrm{~h}$ on night.

On day 14 the soil samples were collected to analyze the activity of phosphatases. The acid phosphomonoesterase - Pac (EC 3.1.3.2) and alkaline phosphomonoesterase - Pal (EC 3.1.3.1) activities were determined as described by Tabatabai and Bremner [1969]. The phosphotriesterase - PT (EC 3.1.8.1) activity was determined according to Eivazi and Tabatabai [1977]. The yellow-band absorbance of the filtrate due to $\mathrm{p}$ nitrophenol was measured at $400 \mathrm{~nm}$. The inorganic pyrophosphatase - IPP (EC 3.1.6.1) activity was measured by Dick and Tabatabai [1978] method. Released orthophosphate was extracted with sulfuric acid, and determined photometrically at $700 \mathrm{~nm}$ after colorization with ammonium molybdate. Enzyme activities were calculated using a calibration curve. Shimadzu UV-VIS 1800 equipment was used in all measurements.

Phosphatase activity determinations were performed on three replicates for each treatment, and the significance of the observed differences was verified using a one-way analysis of variance followed by the post-hoc Tukey's HSD test. Differences with a $p$ value of $<0.05$ were considered as significant.

Additionally, mean activity of phosphatase of samples treated with all dosages of ionic liquid was used to calculate the index of enzymatic resistance (RS) according to the formula developed by Orwin and Wardle [2004]:

$$
\mathrm{RS}=1-\frac{2|\mathrm{D}|}{\mathrm{C}+|\mathrm{D}|}
$$

where $C$ is the soil resistance under natural conditions (not exposed to ILs) and P the resistance of soil exposed to ILs; $\mathrm{D}=\mathrm{C}-\mathrm{P}$.

Based on the analysis of the effect measure $\eta^{2}$ by variance analysis - ANOVA - the percentage shares of all variable factors affecting the activity of phosphatases were also defined. 


\section{RESULTS AND DISCUSSION}

Activity of alkaline phosphomonoesterase (Pal), acid phosphomonoesterase (Pac), phosphotriesterase (PT) and inorganic pyrophosphatase (IPP) in control soil (without ILs) was as follows: $174.54-186.02 \mathrm{mg}$ - $\mathrm{NP} / \mathrm{kg} \mathrm{DM} / \mathrm{h}$, 116.26-145.76 mg p-NP/kg DM/h, 22.22-23.26 $\mathrm{mg} \mathrm{p}-\mathrm{NP} / \mathrm{kg} \mathrm{DM} / \mathrm{h}$ and 406.34-487.71 $\mathrm{mg}$ $\mathrm{P}-\mathrm{PO}_{4}{ }^{3-} / \mathrm{kg} \mathrm{DM} / \mathrm{h}$, respectively.

Application of different dosages of [Pyrrol] [PF6] caused mainly non-significant changes in activity of all phosphatases. Significant decrease in activity of Pal was observed only in soil treated with [Pyrrol][PF6] at the dosage of $50 \mathrm{mg} / \mathrm{kg} \mathrm{DM}$ (30.71\% compared to control). Inhibition of Pac was also reported in soil containing [Pyrrol][PF6] at dosages: 700 and $1000 \mathrm{mg} / \mathrm{kg} \mathrm{DM} \mathrm{(35.04} \mathrm{and}$ $41.19 \%$ compared to control, respectively). Additionally, this IL at the dosage of $1000 \mathrm{mg} / \mathrm{kg}$ decreased in IPP activity (24.80\% compared to control). However in soil with [Pyrrol][PF6] at the dosage of $10 \mathrm{mg} / \mathrm{kgDM}$ a stimulation of IPP was noted (25.89\% compared to control) (Table 1$)$.

Similarly to [Pyrrol][PF6], after treatment with [Piper][PF6] mostly non-significant changes in activity of PT and also IPP were observed. Sig- nificant increase of IPP activity appeared only in soil with addition of [Piper][PF6] at the dosage of $1 \mathrm{mg} / \mathrm{kg}$ DM (56.11\% compared to the control). Whereas, application of this IL mainly significantly affected Pal and Pac activities. In the soil containing [Piper][PF6] at dosages of: 1, 50 and $100 \mathrm{mg} / \mathrm{kg} \mathrm{DM}$ a significant stimulation of Pal activity was noticed $(16.85,15.09$ and $23.86 \%$ compared to the control, respectively). However a significant increase in Pal activity was reported in soil treated with [Piper][PF6] at dosages of 10, 400,700 and $1000 \mathrm{mg} / \mathrm{kg} \mathrm{DM}$ (in the range from 19.95 to $36.40 \%$ compared to the control). Additionally, significant inhibition of Pac occurred after application of this IL at dosages: 10, 50, 400, 700 and 1000 (in the range from 19.72 to $49.79 \%$ compared to the control) (Table 2).

Application of [Piryd][PF6] at the dosages of $1-50 \mathrm{mg} / \mathrm{kg}$ DM did not affect significantly activity of all determined phosphatases (Table 3). This effect was also observed for PT in soil treated with all dosages of [Piryd][PF6]. In soil with [Piryd][PF6] at the dosage of $100 \mathrm{mg} / \mathrm{kg} \mathrm{DM}$ a significant decrease in enzyme activity was observed only for IPP (9.75\% compared to control). Application of this IL at the dosages of 400 and 700 $\mathrm{mg} / \mathrm{kg}$ DM caused a significant inhibition only

Table 1. Activity of soil phosphatases in soil treated with different dosages of [Pyrrol][PF6]

\begin{tabular}{|c|c|c|c|c|}
\hline $\begin{array}{l}\text { ILs dosage } \\
\text { [mg/kg DM] }\end{array}$ & $\begin{array}{c}\text { Pal } \\
{[\mathrm{mg} \mathrm{p}-\mathrm{NP} / \mathrm{kg} \mathrm{DM} / \mathrm{h}]}\end{array}$ & $\begin{array}{c}\text { Pac } \\
{[\mathrm{mg} \mathrm{p}-\mathrm{NP} / \mathrm{kg} \mathrm{DM} / \mathrm{h}]}\end{array}$ & $\begin{array}{c}\mathrm{PT} \\
{[\mathrm{mg} \mathrm{p}-\mathrm{NP} / \mathrm{kg} \mathrm{DM} / \mathrm{h}]}\end{array}$ & 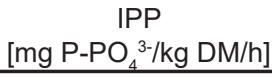 \\
\hline 0 & $179.54 \mathrm{bc}$ & $145.76 \mathrm{a}$ & $23.26 \mathrm{a}$ & $487.71 \mathrm{bc}$ \\
\hline 1 & $215.95 a$ & $147.48 \mathrm{a}$ & $23.26 \mathrm{a}$ & 497.25 bc \\
\hline 10 & $215.24 \mathrm{a}$ & $144.13 \mathrm{a}$ & $24.97 \mathrm{a}$ & $613.99 \mathrm{a}$ \\
\hline 50 & $124.40 \mathrm{~d}$ & $118.03 a b$ & $23.10 \mathrm{a}$ & $535.95 b$ \\
\hline 100 & $208.25 a b$ & $130.87 \mathrm{a}$ & $23.22 \mathrm{a}$ & $469.37 \mathrm{c}$ \\
\hline 400 & $162.47 \mathrm{bc}$ & $135.55 \mathrm{a}$ & $23.16 \mathrm{a}$ & $541.73 b$ \\
\hline 700 & $142.49 \mathrm{~cd}$ & $94.68 \mathrm{bc}$ & $22.21 \mathrm{a}$ & $554.71 \mathrm{~b}$ \\
\hline 1000 & $153.14 \mathrm{bcd}$ & $85.72 \mathrm{c}$ & $21.41 \mathrm{a}$ & $366.77 \mathrm{~d}$ \\
\hline
\end{tabular}

Values denoted with the same letter for each enzyme do not differ statistically at $p<0.05$

Table 2. Activity of soil phosphatases in soil treated with different dosages of [Piper][PF6]

\begin{tabular}{|c|c|c|c|c|}
\hline $\begin{array}{c}\text { ILs dosage } \\
{[\mathrm{mg} / \mathrm{kg} \mathrm{DM}]}\end{array}$ & $\begin{array}{c}\mathrm{Pal} \\
{[\mathrm{mg} \mathrm{p-NP/kg} \mathrm{DM} / \mathrm{h}]}\end{array}$ & $\begin{array}{c}\mathrm{Pac} \\
{[\mathrm{mg} \mathrm{p-NP/kg} \mathrm{DM} / \mathrm{h}]}\end{array}$ & $\begin{array}{c}\mathrm{PT} \\
{[\mathrm{mg} \mathrm{p}-\mathrm{NP} / \mathrm{kg} \mathrm{DM} / \mathrm{h}]}\end{array}$ & $\begin{array}{c}\text { IPP } \\
{\left[\mathrm{mg} \mathrm{P}^{3}-\mathrm{PO}_{4}{ }^{3} / \mathrm{kg} \mathrm{DM} / \mathrm{h}\right]}\end{array}$ \\
\hline 0 & $174.30 \mathrm{~b}$ & $143.63 \mathrm{a}$ & $22.22 \mathrm{a}$ & $406.34 \mathrm{~b}$ \\
\hline 1 & $203.68 \mathrm{a}$ & $146.23 \mathrm{a}$ & $23.23 \mathrm{a}$ & $634.35 \mathrm{a}$ \\
\hline 10 & $110.86 \mathrm{~d}$ & $94.96 \mathrm{c}$ & $24.76 \mathrm{a}$ & $455.74 \mathrm{~b}$ \\
\hline 50 & $200.61 \mathrm{a}$ & $115.31 \mathrm{~b}$ & $21.93 \mathrm{a}$ & $417.51 \mathrm{~b}$ \\
\hline 100 & $215.89 \mathrm{a}$ & $129.99 \mathrm{ab}$ & $21.49 \mathrm{a}$ & $481.87 \mathrm{~b}$ \\
\hline 400 & $139.53 \mathrm{c}$ & $85.90 \mathrm{~cd}$ & $24.43 \mathrm{a}$ & $442.41 \mathrm{~b}$ \\
\hline 700 & $128.85 \mathrm{~cd}$ & $79.47 \mathrm{~cd}$ & $23.70 \mathrm{a}$ & $427.28 \mathrm{~b}$ \\
\hline 1000 & $124.87 \mathrm{~cd}$ & $72.11 \mathrm{~d}$ & $19.25 \mathrm{a}$ & $487.97 \mathrm{~b}$ \\
\hline
\end{tabular}

Values denoted with the same letter for each enzyme do not differ statistically at $p<0.05$ 
Table 3. Activity of soil phosphatases in soil treated with different dosages of [Piryd][PF6]

\begin{tabular}{|c|c|c|c|c|}
\hline $\begin{array}{c}\text { ILs dosage } \\
{[\mathrm{mg} / \mathrm{kg} \mathrm{DM}]}\end{array}$ & $\begin{array}{c}\mathrm{Pal} \\
{[\mathrm{mg} \mathrm{p}-\mathrm{NP} / \mathrm{kg} \mathrm{DM} / \mathrm{h}]}\end{array}$ & $\begin{array}{c}\mathrm{Pac} \\
{[\mathrm{mg} \mathrm{p}-\mathrm{NP} / \mathrm{kg} \mathrm{DM} / \mathrm{h}]}\end{array}$ & $\begin{array}{c}\mathrm{PT} \\
{[\mathrm{mg} \mathrm{p}-\mathrm{NP} / \mathrm{kg} \mathrm{DM} / \mathrm{h}]}\end{array}$ & $\begin{array}{c}\text { IPP } \\
{\left[\mathrm{mg} \mathrm{P}_{-} \mathrm{PO}_{4}{ }^{3} / \mathrm{kg} \mathrm{DM} / \mathrm{h}\right]}\end{array}$ \\
\hline 0 & $186.02 \mathrm{ab}$ & $116.26 \mathrm{a}$ & $22.25 \mathrm{a}$ & $452.28 \mathrm{~b}$ \\
\hline 1 & $199.71 \mathrm{a}$ & $111.00 \mathrm{a}$ & $25.05 \mathrm{a}$ & $431.94 \mathrm{bc}$ \\
\hline 10 & $178.93 \mathrm{ab}$ & $96.73 \mathrm{ab}$ & $26.05 \mathrm{a}$ & $506.83 \mathrm{ab}$ \\
\hline 50 & $158.25 \mathrm{bc}$ & $96.73 \mathrm{ab}$ & $21.26 \mathrm{a}$ & $497.15 \mathrm{~b}$ \\
\hline 100 & $150.30 \mathrm{bcd}$ & $96.06 \mathrm{ab}$ & $18.78 \mathrm{a}$ & $408.18 \mathrm{c}$ \\
\hline 400 & $129.89 \mathrm{cde}$ & $85.90 \mathrm{ab}$ & $19.12 \mathrm{a}$ & $469.99 \mathrm{~b}$ \\
\hline 700 & $110.11 \mathrm{de}$ & $79.47 \mathrm{ab}$ & $21.14 \mathrm{a}$ & $453.85 \mathrm{~b}$ \\
\hline 1000 & $115.43 \mathrm{e}$ & $72.11 \mathrm{~b}$ & $20.01 \mathrm{a}$ & $568.42 \mathrm{a}$ \\
\hline
\end{tabular}

Values denoted with the same letter for each enzyme do not differ statistically at $p<0.05$

of Pal activity (30.17 and $40.81 \%$ compared to the control, respectively). However treating soil with the highest dosage $(1000 \mathrm{mg} / \mathrm{kg} \mathrm{DM})$ of [Piryd][PF6] resulted in significant decrease in $\mathrm{Pal}$ and Pac activity (37.95 and 37.97\% compared to control, respectively) and an increase IPP activity (25.68\% compared to control).

An interpretation of the effect of different ILs and any other pollutant on soil phosphatase activities is difficult because the enzyme assays currently used have some limitations and because of the existence of direct and indirect effects on the measured enzyme [Nannipieri et al., 2003]. For example, inhibition of enzyme activity by a pollutant may be masked by growth of surviving microorganisms which are characterised with expression of genes codifying the enzyme. A relative increase of biomass is a result of growing population of microorganisms which survive a toxic treatment and may feed on microbial remains of organisms which do not survive it [Nannipieri et al., 2011]. According to Griffiths and Philippot [2013] the index of enzymatic resistance values can be used to determine the sensitivity of analysed ecosystem to various stressors. Soil resistance indicators provide information about the status of soil environments contaminated with organic compounds [Kaczyńska et al., 2015]. Additionally Parelho et al. [2016] reported that soil phosphatases are important factors in the process of organic phosphorus compounds transformation to inorganic phosphates, and they are very often used as the indicator of soil fertility.

It was found, based on the calculated values of resistance index (RS), that among all phosphatases, the most sensitive to the ILs analysis in soil were Pal and Pac. The RS values for the soil treated with [Pyrrol][PF 6 , [Piper][PF6] and [Piryd][PF6], in case of Pal, were 0.67, 0.54 and 0.43 , respectively, and in case of Pac 0.67, 0.56 and 0.57 , respectively (Fig. 1). The values of RS calculated for PT and IPP were significantly higher, in the range of 0.79-0.94 and 0.77-0.85, respectively.

Results obtained by Sun et al. [2017] revealed that acid phosphatase, as well as dehydrogenase, was not sensitive to 1-methyl-3-octylimidazoli-

$\square[$ Pyrrol][PF6] $\quad \square[$ Piper][PF6] $\quad \square[$ Piryd][PF6]

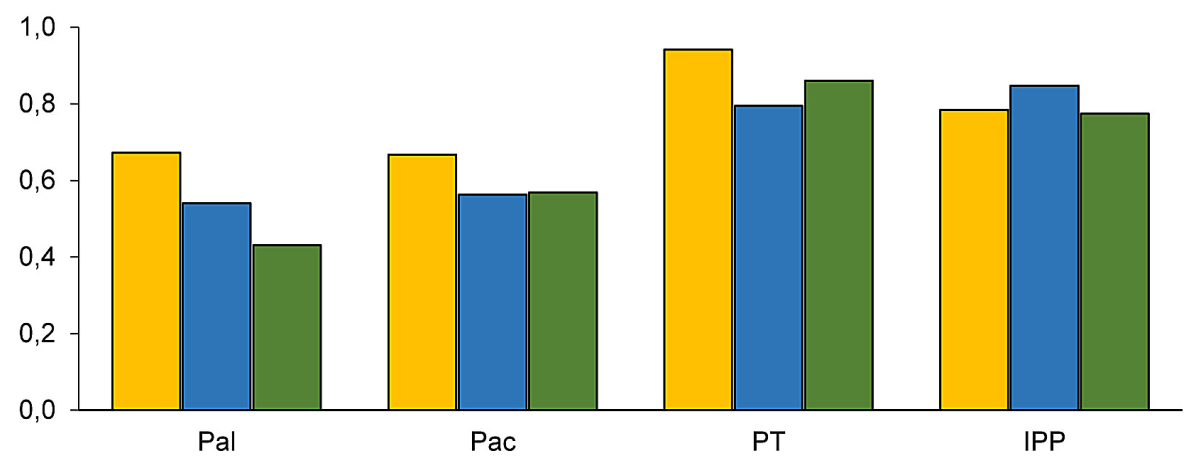

Figure 1. Mean resistance indices of phosphatase activitis in soil treated with [Pyrrol][PF6], [Piper][PF6] and [Piryd][PF6] 
um tetrafluoroborate, while urease activity was first stimulated and then inhibited by this IL (observed after 30-day incubation). Telesiński and Sułkowska [2016] reported that two imidazolium ionic liquids: 3-butyl-1-methylimidazolium tetrafluoroborate and 3-hexyl-1-methylimidazolium tetrafluoroborate, decreased activity of o-diphenol oxidase, but the size of this effect depended on a dosage of ILs, incubation time and soil properties. However, Li et al. [2013] showed that imidazolium ionic liquids may improve enzyme activities because they participate in biocatalytic processes.

The data presented in Table 4 indicated unequivocally that the activity of phosphatases varied depending on the type and the dosages of ILs. The share of types of IL took the major role in the formation of Pac activity (56.67\%). However, the activity of Pal and PT was mainly formed by IL dosages (57.33 and 50.69\%, respectively). In contrast, for IPP activity the highest impact was observed in case of interaction between both: a type and a dosage of ILs. Our previous studies showed that effect of different ionic liquids on biochemical parameters of soil and plants largely depended on the structure of the examined ILs cations, IL dosages and type of anion [Biczak, 2016, Biczak et al., 2014, 2016a, 2016b, Telesiński 2012, Telesiński and Sułkowska 2016].

\section{CONCLUSIONS}

In the present study, the effects of three different ionic liquids with hexafluorophosphate anion: [Pyrrol][PF6], [Piper][PF6] and [Piryd] [PF6] on soil phosphatase activities were examined. First, the application of different dosages of all ILs caused mainly non-significant changes in all phosphatase activities. Secondly, changes in phosphatase activities were often not dependent on IL dosages, but the most sensitive for ILs were phosphomonoesterases. Thirdly, type of ILs affected mainly activity of acid phosphomonoes- terase, while dosages of ILs activity of alkaline phosphomonoesterase and phosphotriesterase. The result of the presented study is beneficial for future research about ILs toxicity.

\section{REFERENCES}

1. Biczak R. 2016. Quaternary ammonium salts with tetrafluoroborate anion: Phytotoxicity and oxidative stress in terrestrial plants. J. Hazard. Mat. 304, 173-185.

2. Biczak R., Pawłowska B., Białczewski R., Rychter P. 2014. The role of the anion in the toxicity of imidazolium ionic liquids. J. Hazard. Mat. 274, 181-191.

3. Biczak R., Pawłowska B., Telesiński A., Ciesielski W. 2016a. The effect of the number of alkyl substituents on imidazolium ionic liquids phytotoxicity and oxidative stress in spring barley and common radish seedlings. Chemosphere 165, 519-528.

4. Biczak R., Telesiński A., Pawłowska B. 2016b. Oxidative stress in spring barley and common radish exposed to quaternary ammonium salts with hexafluorophosphate anion. Plant Physiol. Biochem. 107, 248-256.

5. Bielińska E.J., Baranowska E., Jędruch M., Gostkowska K. 2005. Ocena stanu środowiska glebowego ogrodów działkowych z terenów o różnym oddziaływaniu antropopresji poprzez badanie aktywności fosfataz [Appraisal of allotment soil environment from areas under the varying influence of anthropopressure through analysis of phosphatase activity]. Inż. Ekolog. 13, 26-28.

6. Bielińska, E.J., Mocek-Płóciniak, A. 2010. Impact of ecochemical soil conditions on selected heavy metals content in garden allotment vegetables. Pol. J. Environ. Stud. 19(5), 895-900.

7. Borowiecki P., Bretner M., Plenkiewicz J. 2015. Ciecze jonowe oraz obszary ich zastosowań w przemyśle chemicznym [Ionic liquids and potential areas of their applications in chemical industry]. Wiad. Chem. 69(3-4), 271-296.

8. Docherty K.M., Kulpa C.F.Jr. 2005. Toxicity and antimicrobial activity of imidazolium and pyridinium ionic liquids. Green Chem. 7, 185-189.

9. Dong M., Zhu L., Zhu S., Wang J., Wang J., Xie H., Du Z. 2013. Toxic effects of 1-decyl-3-methy-

Table 4. Participation of variable factors in the formation of phosphatase activities [\%]

\begin{tabular}{|l|c|c|c|c|}
\hline \multicolumn{1}{|c|}{ Variable factors } & Pal & Pac & PT & IPP \\
\hline Type of ILs (A) & 22.26 & 56.67 & 26.18 & 29.86 \\
\hline Dosage of ILs (B) & 57.33 & 39.04 & 50.69 & 18.75 \\
\hline A $\times$ B & 19.00 & 3.61 & 13.72 & 43.59 \\
\hline Error & 1.41 & 0.68 & 9.41 & 7.81 \\
\hline
\end{tabular}


limidazolium bromide ionic liquid on the antioxidant enzyme system and DNA in zebrafish (Danio rerio) livers. Chemosphere 91, 1107-1112.

10. Griffiths B.S., Philippot L. 2013. Insights into the resistance and resilience of the soil microbial community. FEMS Microbiol. Rev. 37(2), 112-129.

11. Kaczyńska G., Borowik A., Wyszkowska J. 2015. Soil dehydrogenases as an indicator of contamination of the environment with petroleum products. Water Air Soil Pollut. 226(11), 372.

12. Li X., Luo Y., Yun M., Wang J., Wang J. 2010. Effects of 1-methyl-3-octylimidazolium bromide on the anti-oxidant system of earthworm. Chemosphere 78, 853-858.

13. Li N., Du W., Huang Z., Zhao W., Wang S., 2013. Effect of imidazolium ionic liquids on the hydrolytic activity of lipase. Chin. J. Catal. 34, 769-780.

14. Liu T., Guo Y., Wang J., Wang J., Zhu L., Zhang J., Zhang C. 2015. Assessing toxic effects of [Omim] Cl and [Omim]BF4 in zebrafish adults using a biomarker approach. Environ. Sci. Pollut. Res. 23, 7360-7368.

15. Nannipieri P., Ascher J., Ceccherini M.T., Landi L., Pietramellara G., Renella G. 2003. Microbial diversity and soil functions. Eur. J. Soil Sci. 54, 655-670.

16. Nannipieri P., Giagnoni L., Landi L., Renella G. 2011. Role of phosphatase enzymes in soil. In: Bünemann E.K., Oberson A., Frossard E. (Eds.), Phosphorus in action. Springer-Verlag, Berlin, Heidelberg, 215-243.

17. Orwin K.H., Wardle D.A. 2004. New indices for quantifying the resistance and resilience of soil biota to exogenous disturbance. Soil Biol. Biochem. 36, 1907-1912.
18. Parelho C., Rodrigues A.S., Barreto M.C., Ferreira N.G.C., Garcia P. 2016. Assessing microbial activities in metal contaminated agricultural volcanic soils - an integrative approach. Ecotoxicol. Environ. Saf. 129, 242-249.

19. Romero A., Santos A., Tojo J. Rodríquez A. 2008. Toxicity and biodegradability of imidazolium ionic liquids. J. Hazard. Mater. 151, 268-273.

20. Sun X., Zhu L., Wang J., Wang J., Su J., Liu T., Zhang C., Gao C., Shao Y. 2017. Toxic effects of ionic liquid 1-octyl-3-methylimidazolium tetrafluoroborate on soil enzyme activity and soil microbial community diversity. Ecotox. Environ. Saf. 135, 201-208.

21. Telesiński 2012. Zmiany parametrów biochemicznych i tok- sykologicznych gleb pod wpływem 1-alkilo-3-metylo-imidazoliowych cieczy jonowych [Change of biochemical and toxicological parameters of soils due to 1-alkyl-3-methylimidazolium ionic liqiuds]. Wyd. Uczelniane Zachodniopomorskiego Uniwersytetu Technologicznego w Szczecinie, Szczecin.

22. Telesiński A., Sułkowska N. 2016. Dynamika zanikania 1-alkilo-3-metyloimidazoliowych cieczy jonowych $\mathrm{w}$ aspekcie ich oddziaływania na aktywność oksydazy o-difenolowej w glebie [Dissipation dynamic of 1-alkyl-3-methylimidazolium ionic liquids and their effect on o-diphenol oxidase activity in soil]. Chem. Environ. Biotechnol. 19, 87-92.

23. Wang J.B., Chen Z.H., Chen L.J., Zhu A.N., Wu Z.J. 2011. Surface soil phosphorus and phosphatase activities affected by tillage and crop residue input amounts. Plant Soil Environ. 57, 251-257. 